\title{
MANAJEMEN MUTU TERPADU
}

Diajukan untuk memenuhi salah satu tugas kelompok pada mata kuliah MANAJEMEN SEKOLAH yang di simpu oleh :

Wahyu Bagja Sulfemi, M.Pd

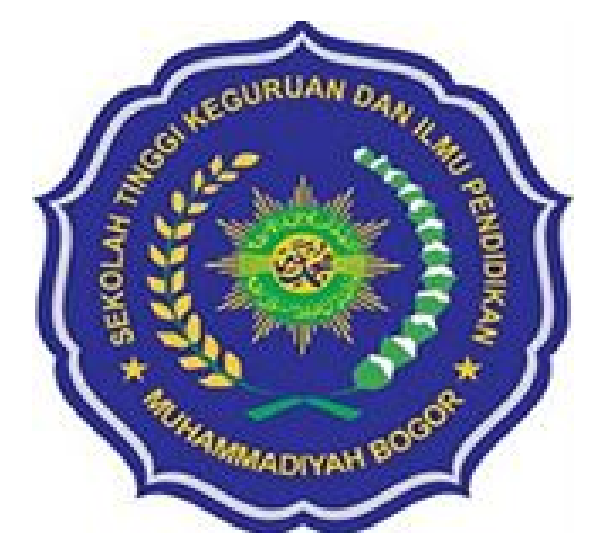

Disusun oleh : kelompok 7

Maya Marta Dinata

NIM : 0142S1A018030

\section{STKIP MUHAMMADIYAH BOGOR PROGRAM STUDI ADMINISTRASI PENDIDIKAN \\ TAHUN 2019}




\begin{abstract}
ABSTRAK
Manajemen mutu terpadu merupakan suatu sistem manajemen yang melibatkan semua unsurdan aspek dalam perbaikan mutu dan berorientasi pada mutu.

Manajemen mutu lembaga pendidikan sebagai sebuah organisasi harus selalu berprinsip pada pemenuhan kebutuhan pelanggan dengan sebaik-baiknya dalam setiap usahanya. Melalui manajemen yang baik, penjaminan mutu juga memberikan informasi pada masyarakat sesuai sasaran dan waktu secara konsisten, dan bila mungkin, membandingkan standar yang telah dicapai dengan standar pesaing. Manajemen penjaminan mutu merupakan bagian integral dalam membangun imej dalam sebuah sekolah atau lembaga pendidikan.
\end{abstract}




\section{PEMBAHASAN MATERI}

1. Pengertian Manajemen Mutu Terpadu

Manajemen tidak akan terlelpas dari kegiatan pemebelajaran karena manajemen tersebut merupakan usaha untuk mensukseskan suatu tujuan dalam pendidikan.

Manajemen adalah proses bekerja sama antara individu dengan kelompok serta sumber daya lainnya dalam mencapai tujuan organisasi adalah sebagai aktivitas manajerial (Harsey,1988:4)

Manajemen adalah metode yang digunakan administrator dalam melaksanakan tugas-tugas tertentu untuk mencapai tujuan tertentu, Secara umum, manajemen adalah suatu proses dimana seseorang dapat mengatur segala sesuatu yang dikerjakan oleh individu atau kelompok. Manajemen perlu dilakukan guna mencapai tujuan atau target dari individu ataupun kelompok tersebut secara kooperatif menggunakan sumber daya yang tersedia.

Mutu Terpadu merupakan kondisi yang berkembang secara terus menerus dalam kajian manajemen, khususnya manajemen pendidikan. Dengan kata lain, manajemen mutu berkembang sejalan dengan berkembangnya kompleksitas permasalahan yang dihadapi dunia pendidikan. Konsep mutu bukan hanya bercakup kesesuaian atribut suatu produk atau program dengan tuntutan publik, namun kulaitas harus dipandang dalam konsep dan cakupan yang lebih luas.

Tak bisa dipungkiri bahwa manajemen memiliki peran yang sangat penting dalam pencapaian tujuan sebuah oragnisasi atau kegiatan. Manajemen menjadi begitu penting karena ia terkait dengan bagaimana mengelola seluruh potensi sumber daya yang 
ada dengan efektif dan efisien dalam rangka mencapai tujuan dan sasaran yang telah ditetapkan.

Manajemen mutu lembaga pendidikan sebagai sebuah organisasi harus selalu berprinsip pada pemenuhan kebutuhan pelanggan dengan sebaik-baiknya dalam setiap usahanya.

Total quality manajement (TQM) atau manajemen mutu terpadu merupakan suatu sistem manajemen yang melibatkan semua unsur dan aspek dalam perusahaan dalam perbaikan mutu dan berorientasi pada mutu.

Konsep TQM harus dimengerti, dipahami dan diterapkan secara sinergis, efisien dan efektif dalam semua aktivitas dilingkungan perusahaan demi tercapainya tujuan, sasaran dan target produktivitas sesuai dengan kebijakanpimpinan puncak.

Awal dari gerakan manajemen mutu adalah diterapkannya sistem inpeksi mutu (Quality insfection) ada tahun 1910, yang menekankan pada tindakan yang benar dan identifikasi sumbersumber yang tidak sesuai. Kemuadian diikuti oleh penerapan pengawasan mutu (quality Controll) tahun 1924, yang ditandai dengan penerapan manual mutu, pengawasan produk.

2. Peningkatan Mutu Melalui Total Quality Management

Evaluasi sebagai langkah perbaikan, dilaksanakan dari lapisan manajemen yang paling bawah sampai manajemen teratas. Evaluasi secara menyeluruh dan totalitas dengan koordinasi yang tepat dan sistematis akan menghasilkan tujuan yang optimal. Perbaikan yang bertahap, tepat dan sistematis akan dapat mencapai tujuan yang optimal jika dilakukan pada tiap departemen yang terkecil dengan penerapan total quality management.

Mutu pembelajaran (Proses), civitas akademik (tools) dan 
lulusan (product) merupakan hal yang sangat diperhatikan. Perbaikan mutu tersebut ditempuh dengan penerapan TQM dipendidikan tinggi. Hal ini ditempuh untuk menjawab tantangan globalisasi, baik dunia pendidikan maupun dunia kerja untuk lulusan [Suranto, 2006].

3. Tujuan penerapan Total Quality Management

Ekroman (2005) menjelaskan bahwa penerapan TQM dan quality Assurance sebagai jaminan mutu yang dipilih sebagai salah satu system untuk memperbaiki mutu penyelenggaraan pendidikan di lembaga pendidikan paling tidak melibatkan tujuh komponen utama yaitu

a. Keterlibatan total dari seluruh civitas academica

2. Mengembangkan iklim organisasi yang bermutu

3. Adanya pusat penjamin mutu yang indepent

4. Adanya indikator kinerja yang berkaitan dengan dengan mutu pembelajaran, penelitian dan pengabdian kepada masyarakat yang secara sadar ditetapkan dan menjadi komitmen bersama

5. Ketersediaan bebagai instrument dan ukuran kinerja/benchmarking untuk mendeteksi peningkatan mutu input, proses, output dan outcome

6. Pengulangan proses perbaikan

7. Komitmen untuk meningkatkan mutu secara terus menerus. 

DAFTAR PUSTAKA

1. Sulfemi, Wahyu Bagja. (2018). Manajemen Kurikulum di Sekolah. Bogor : Visi Nusantara

2. Suranto,2009. Manajemen Mutu Dalam Pendidikan. Semarang:CV.Ghyyas Putra

3. Rahman.Bujang,2013.Manajemen Mutu Lembaga Pendidikan Tenaga Kependidikan.Yogyakarta: Graha IImu

Soal PG

1. Proses bekerja sama Antara individu dengan kelompok serta sumber daya lainnya dan mencapai tujuan organisasi adalah
a. Manajemen
b. Kurikulum
c. Pendidikan
d. Mutu terpadu

2. Proses bekerja sama Antara individu dengan kelompok serta sumber daya lainnya dan mencapai tujuan organisasi adalah
a. Harsey
b. James
c. Harold
d. Edgar

3. Sistem manajemen yang melibatkan semua unsur dan aspek dalam perusahaan dalam perbaikan mutu dan berorientasi pada mutu disebut

a. Manajemen mutu 
b. Manajemen kurikulum

c. Manajemen sekolah

d. Manajemen pendidikan

4. Dipahami dan diterapkan secara sinergi, efisien dan efektif dalam semua aktivitas merupakan ..... Dalam manajemen mutu terpadu
a. Konsep
b. Tujuan
c. Dasar
d. Manfaat

5. Mutu merupakan kondisi yang berkembang secara teru menerus dalam kajian menejemen khususnya manajemen pendidikan adalah gagasan menurut
a. Deming dan edward
b. Redmond
c. Curtis dan keenan
d. Noone

6. langkah perbaikan, dilaksanakan dari lapisan manajemen yang paling bawah sampai manajemen teratas
a. Evaluasi
b. Proses
c. Perbandingan
d. Perbaikan

7. Penerapan pengawasan mutu atau quality Controll didirikan tahun
a. 1924
b. 1925 
c. 1926

d. 1927

8. Ada berapakah tujuan penerapan TQM menurut ekroman

a. 7

b. 6

C. 5

d. 4

9. Tujuan penerapan TQM yang d gagaskan oleh Ekroman pada tahun?

a. 2005

b.2006

c. 2007

d. 2008

10. Salah Satu sistem untuk memperbaiki mutu penyelenggaraan pendidikan di lembaga pendidikan adalah
a. Total quality Management
b. Quality Assurance
c. Total quality Controll
d. Quality Management

Soal Essay

1. yang di maksud dengan manajemen mutu terpadu?

2. Untuk apa evaluasi TQM di lakukan? 
3. Sebutkan 7 tujuan penerapan TQM menurut Ekroman?

4. Apa yang di maksud dengan perbaikan mutu meurut suranto?

5. Menurutmu penting kah manajmen mutu terpadau? Jawaban

$\mathrm{Pg}$

1. a

2. $a$

3. $a$

4. $a$

5. a

6. a

7. $a$

8. a

9. a

10. a

Essay

1. Mutu Terpadu merupakan kondisi yang berkembang secara terus menerus dalam kajian manajemen, khususnya manajemen pendidikan.

2. Evaluasi sebagai langkah perbaikan, dilaksanakan dari lapisan manajemen yang paling bawah sampai manajemen teratas. Evaluasi secara menyeluruh dan totalitas dengan koordinasi yang tepat dan sistematis akan menghasilkan tujuan yang optimal.

3. a. Keterlibatan total dari seluruh civitas academica

b. Mengembangkan iklim organisasi yang bermutu 
c. Adanya pusat penjamin mutu yang indepent

d. Adanya indikator kinerja yang berkaitan dengan dengan mutu pembelajaran, penelitian dan pengabdian kepada masyarakat yang secara sadar ditetapkan dan menjadi komitmen bersama

e. Ketersediaan bebagai instrument dan ukuran kinerja/benchmarking untuk mendeteksi peningkatan mutu input, proses, output dan outcome

f. Pengulangan proses perbaikan

g. Komitmen untuk meningkatkan mutu secara terus menerus.

4. Perbaikan mutu tersebut ditempuh dengan penerapan TQM dipendidikan tinggi. Hal ini ditempuh untuk menjawab tantangan globalisasi, baik dunia pendidikan maupun dunia kerja untuk lulusan [Suranto, 2006]

5. Manajemen mutu terpadu menurut saya penting karena mangemen ini menyangkut mutu pembelajaran di sekolah yang dimana pembelajaran ini sangat penting bagi lingkungan pendidikan karena ini termasuk manajemen sekolah yang mencakup lingkungan sekolah 